\title{
Review
}

\section{Towards an improper politics}

\author{
Mark Devenney \\ Edinburgh, Edinburgh University Press 2020, 224 pp., \\ ISBN: 9781474454032
}

Contemporary Political Theory (2022) 21, S23-S26. https://doi.org/10.1057/s41296021-00475-z; published online 23 February 2021

Mark Devenney's Towards an Improper Politics centers property and its close kin, propriety, as the animating problem for political theory today. The challenge he undertakes is to articulate the sedimented inequalities of property within the terms of post-foundational political theory, in which action and identities are understood in contingent, situational, and relational terms. How, then, to reckon with the persistence of property, even as it emerges in new neoliberal formations as both a driver of material inequality and an object of political struggle? And how to do so without reinscribing fixed terms of contentious subjectivities and movements in advance? Devenney's improper politics tackles these questions through a renewed openness and attention to novel forms of political action and solidarities that challenge transnational structures of inequality and dispossession. In this way, Towards an Improper Politics puts pressure on post-foundational theory to make good on its insights for the express purpose of dismantling economic inequality.

Devenney's project proceeds from a charitably critical engagement with Ernesto Laclau and Chantal Mouffe's challenge to class as the organizing category of left politics. While sympathetic to their efforts to decenter class in order to render intelligible a broader field of contingent political identities and struggles, he sees an unfinished project of understanding challenges to proprietary power within that expanded field of vision. Eschewing an ontological commitment to a revolutionary working class need not mean that post-foundational political thought has nothing to say about material inequality and the power relations structured by property. So Devenney builds from Laclau and Mouffe's opening and decentering gestures, while challenging their efforts to theorize contingent but necessary moments of closure.

The strength of the book is Devenney's knowledgeable and subtle engagement with a range of post-foundational thinkers, bringing forward and accentuating what is useful among its interlocutors. This generative spirit is evident in chapter four's discussion of Marx on property, and it especially shines through in the discussions of Judith Butler as well as Laclau and Mouffe. It is Jacques Rancière, however,

(c) 2021 The Author(s), under exclusive licence to Springer Nature Limited part of Springer Nature. 14708914 Contemporary Political Theory Vol. 21, S1, S23-S26 www.palgrave.com/journals 
who serves as Devenney's most constant theoretical companion. With Rancière, Devenney turns away from the post-Saussurean linguistics that serve as the underlying architecture for Laclau and Mouffe's thought toward a disruptive aesthetic excess. Challenging property is always improper, in terms of both social intelligibility and ownership, and this impropriety is a key feature of the democratic politics we need. Devenney seeks a post-foundational politics that is focused on the uncounted claims and claimants that disrupt and reorient the political scene in ways that are conventionally unintelligible. Without longing for a return of a revolutionary subject, whether the working class or a new commons, Devenney reorients the reader's vision toward an open horizon awaiting disruptive moments in the neoliberal networks of proprietary power.

This horizon is rendered vivid to the reader by Devenney's foregrounding of diverse and localized examples of improper politics that open each chapter. These exemplary instances of improper politics naturally include the Occupy Movement as well as others more historically and geographically dispersed, from a 1993 museum exhibition in South Africa, to a 1980 theatrical performance in Derry, to protests across the globe of varied forms of dispossessions of land and nation. These practices of disruption, disparate though they are in aims and risks, provide a welcome interjection of empirical, situated political encounters, by turns embodied, theatrical, object-oriented, and locally situated. There is no single political subjectivity that captures these political efforts, nor are they part of a call for a universal solidarity. Rather, they display different aspects of struggles that simultaneously challenge both property and propriety, broadly construed to extend to questions of territory, sovereignty, and bodily autonomy. They represent emergent forms of political action that target spatial, temporal and material control in what Devenney names 'proprietary orders' (p. 16).

Towards an Improper Politics casts its net very widely in defining democratic politics through diverse challenges to proprietary orders. This improper politics, however, is defined primarily by what it is not, save a single requirement: a commitment to, or better, an enactment of equality. This rather abstract, even universal, value of equality winds up doing a lot of work in securing the link between an improper politics and its democratic character. It is this egalitarian quality that allows Devenney to claim democratic forms of populism, while eschewing nationalist and other exclusionary forms of politics from his vision of an improper politics. Populism, he writes, 'is not in itself democratic. It is only democratic insofar as it evidences a politics that enacts equality’ (p. 5). While drawing such a distinction between democratic and undemocratic forms of populism seems entirely reasonable, it generates some knotty questions for the grammar of impropriety and the political.

There is no shortage of improper political activity dominating headlines globally in these unsettled times, and much of it is repugnant to egalitarians, left and center. At least a few of the actions that appear on Devenney's list of improper politics,

S24 (c) 2021 The Author(s), under exclusive licence to Springer Nature Limited part of Springer Nature. 14708914 Contemporary Political Theory Vol. 21, S1, S23-S26 
including theft, trespass, piracy, occupation, and hacktivism, sit uncomfortably entwined with an entrenched impropriety on the right. Indeed, when Devenney lists theft and trespass, to take two of these actions, as modes of improper politics, it is (in early 2021) difficult to suppress the image of the lectern of the U.S. Speaker of the House being carried off by Capitol insurgents. This does not undermine Devenney's project, but rather intensifies the significance of its terms. In claiming certain forms of improper politics for democracy, what happens to the vocabulary for denouncing the undemocratic and exclusionary? Are insufficiently democratic forms of populism now improperly improper politics, if one can say such a thing? While the racialized and gendered assertions of individual power advanced in the waning days of the Trump presidency may belong to long-standing political and institutional orders, it does not sound quite right to describe it as a proper politics, that is, as staying within proprietary or institutional orders. Perhaps in some ways it does, but clearly not in others. Devenney's exploration of the intersection between democracy, impropriety, and a rejection of proprietary orders delivers an important reminder. The book poses a strong caution against substituting calls for propriety in any form, whether institutional decorum, civility, or some other norm, for democratic action. Falling back on the language of propriety will not advance the emerging democratic politics we need. I would also ask if impropriety alone is fully up to the intellectual and political work that remains to be done.

The book raises far more subtle and fine-tuned distinctions than the extreme case I pose here, yet it highlights how an improper politics taxes our political vocabulary by rerouting it in sometimes counter-intuitive directions. Perhaps this is the kind of defamiliarizing work we need from political theory, but what new road signs might enhance such new political attunements? Devenney's choices of examples convey a set of judgments as to the democratic character of political actions, but also what counts as political. This is particularly evident in the case of 'hacktivism', which by its very name suggests a distinction from more pedestrian instances of mischief or embezzlement. Are we to read a political character into less overtly politicized terms, such a piracy or theft, or are there degrees and distinctions at work? As the very limits of what counts, or not, as political is at stake, it would deepen the contribution of the book to more openly perform the actions of judging at the limits of political propriety and impropriety. In other words, the exemplary practices of the book could profitably give as much attention to its practice of judgment as to its instances of improper politics.

Towards an Improper Politics advances what I would call a tightrope term, one forever set in tension against its own ostensibly proper origin. The question is whether that unrelenting tension will reverberate energetically or go slack from overextension. Devenney is right to reject the temptation to choose one side, but compelling questions remain about definition and meaning-making in these dark and unsettled political times. I suspect that the negative definition of improper politics retains something of the post-Saussurean commitment to language as a

(C) 2021 The Author(s), under exclusive licence to Springer Nature Limited part of Springer Nature. 1470- S25

8914 Contemporary Political Theory Vol. 21, S1, S23-S26 
system of differences that Devenney otherwise rejects. By contrast, the giving of examples throughout Towards an Improper Politics has the effect of habituating or, we might say, teaching readers to recognize political action and proprietary subversion that more conventional political frames would obscure. If the book's performative action is part of its theoretical contribution-and why shouldn't it be?-it seems that there is something more Wittgensteinian about its engagement with impropriety, in which language is not so much a system of differences as a learning of habits. Devenney wants to change our habits of recognizing political action, but if he is successful in this aesthetic and political reform, do we still speak properly or improperly, of property and impropriety, in the same way? Whether thinking with Ranciére, as Devenney does, or Wittgenstein, as I suggest, a common response may issue not in defining what is proper or improper once and for all, but in attending to those configurations of the 'we' to whom such claims make sense.

Publisher's Note Springer Nature remains neutral with regard to jurisdictional claims in published maps and institutional affiliations.

Torrey Shanks

University of Toronto, Toronto, ON M1C 1A4, Canada torrey.shanks@utoronto.ca

S26 (c) 2021 The Author(s), under exclusive licence to Springer Nature Limited part of Springer Nature. 14708914 Contemporary Political Theory Vol. 21, S1, S23-S26 